\title{
RELEVANSI RESTORATIVE JUSTICE DALAM PENANGANAN ANAK NAKAL
}

\author{
Oleh \\ Rommy Pratama*) \\ rommy.fh@unis.ac.id
}

\section{Abstrak}

Perlindungan terhadap anak ini telah menjadi kesepakatan internasional sebagaimana diamanatkan dalam deklarasi Jenewa tentang Hak Anak-anak tahun 1924, yang selanjutnya telah mendapat pengakuan dalam Deklarasi Sedunia tentang Hak Asasi Manusia serta ketentuan hukum yang dibuat oleh badan-badan khusus dan organisasiorganisasi Internasional yang memberi perhatian bagi kesejahteraan anak-anak. Jauh hari Majelis Umum PBB memaklumkan Deklarasi Hak Anak-Anak dengan maksud agar anakanak dapat menjalani masa kecil yang membahagiakan, berhak menikmati hak-hak dan kebebasan baik kepentingan mereka sendiri maupun untuk kepentingan masyarakat.

\section{Kata Kunci : Hukum Pidana, Penanganan Anak Nakal}

\section{A.PENDAHULUAN}

Undang-Undang No. 3 Tahun 1997 telah mencabut Pasal 45, 46, dan 47 KUHP yang mengatur straf modus dan straf sort tentang sistem pemidanaan untuk anak, dengan tujuan semata-mata untuk memberikan perlindungan dari stigma pada jiwa anak dalam menjalani proses perkara pidana. Namun setelah berjalan selama 10 tahun undang-undang tersebut, pada tataran implementasinya dirasakan tidak dapat memenuhi tujuan dilahirkannya undang-undang dimaksud, karena pendekatan yuridis formal lebih ditonjolkan dan tertutup dilakukannya upaya diskresi dalam mencari solusi perkara anak nakal.

Model peradilan restorative yang lebih menekankan diskresi untuk penyelesaian masalah anak nakal, memberikan alternative diversi sebagai upaya menghindarkan stigma mental anak pada proses hukum. Model peradilan restorative ini, pada tataran ius constotuendum peradilan anak Indonesia adalah suatu pemikiran dalam rangka

*) Penulis adalah Dosen Fakultas Hukum

Universitas Islam Syekh Yusuf perumusan undang-undang peradilan anak. Phenomenon berbagai kelemahan formulasi corak atau model sisistem peradilan anak dalam UU No.3 Tahun 1997 kembali dipertaruhkan, padahal UU ini dianggap formulator sebagai model peradilan anak yang lebih baik dari KUHP yang berkaiatan dengan masalah pengaturan tentang tindak pidana dan, pertanggungjawaban pidana serta pidana dan pemidanaannya, sedangkan KUHAP yang menyangkut masalah hukum proses terutama Pasal 50 s/d 68 selain Pasal 64 KUHAP.

Berangkat dari suara-suara ketidakpuasan sistem peradilan anak di Indonesia yang ada pada ketentuan UU No. 3 Tahun 1997 tersebut, tentu saja tidak luput dari mempermasalahkan penanggulangan kenakalan anak melalui jalur penal yang diwujudkan dalam sistem peradilan pidana anak (juvenile justice sistem). 


\section{B. PEMBAHASAN}

\section{Substansi Formulatif keberadaan Undang-Undang Pengadilan Anak}

Untuk mengetahui peta permasalahan tentang kenakalan anak sebagai kajian, dimana kenakalan anak dalam masyarakat disebabkan ditemukan perilaku anak yang bertentangan dengan norma yang ada dalam masyara-kat di samping norma hukum. Fenomena perilaku anak yang bertentangan dengan norma-norma yang ada dalam masyarakat itu perlu difahami dalam rangka untuk penanggulangannya.

Reaksi masyarakat untuk menanggulangi prilaku yang bertentangan dengan norma itu dalam hukum pidana dan kriminologi disebut dengan kebijakan kriminal. Dalam hal kebijakan kriminal tersebut, Sudarto mendefinisikan dengan menyitir pendapat Marc Ancel dan G.P.Hoefnagels bahwa kebijakan kriminal itu merupakan suatu usaha rasional dari masyarakat untuk menanggulangi kejahatan yang meliputi seluruh azas dan metode yang mendasari reaksi terhadap pelanggaran hukum pidana, keseluruhan fungsi aparat penegak hukum dan kebijakan undang-undang dan badanbadan resmi untuk menegakkan norma masyarakat. ${ }^{1}$

Upaya penanggulangan kenakalan anak melalui jalur penal lebih bersifat represif, berbeda dengan upaya jalur non penal yang aksentisasinya yang bersifat preventif. Namun menurut Barda Nawawi Arief, pada hakikatnya tindakan represif juga dapat dilihat sebagai tindakan preventif dalam arti luas. ${ }^{2}$

1 Sudarto, Hukum dan Hukum Pidana, (Bandung : Alumni, 1977), halaman 6

2 Barda Nawawi Arief, Bunga Rampai Kebijakan Hukum Pidana, (Bandung : Citra Aditya Bakti, 1996), halaman 49
Pengkajian terhadap kenakalan anak yang menyangkut tentang anak nakal dalam kebijakan penal, Paulus Hadisuprapto menuturkan bahwa, ${ }^{3}$ baik dari kalangan legislative, eksekutif maupun yudikatif lebih memfokuskan kepada sarana penal yaitu ius constitutum dan ius operatum belaka dan mengabaikan kebijakan non penal. Sehubungan dengan kebijakan penal dalam ius constitutum dan ius operatum untuk penanggulangan anak nakal di Indonesia, ternyata masih menimbulkan permasalah dalam perlindungan terhadap anak.

Telaah terhadap hukum positif yang terkait dengan anak nakal adalah meliputi pengaturan yang tersebar dalam undang-undang pidana yang mengatur masalah anak, yaitu Pasal 45, 46, dan 47 KUHP, Pasal 50 s/d 68 KUHAP selaian Pasal 64 KUHAP. UU No.3 tahun 1997 tentang Pengadilan Anak, UU No.4 tahun 1979 tentang Kesejahteraan Anak, Keppres No. 36 Tahun 1990 tentang pengesahan Konvensi Hak-Hak Anak, dan UU No. 23 Tahun 2002 tentang Perlindungan Anak, khususnya Pasal 16, 17, 59, 64 Anak baik secara fisik maupun mental membutuhkan perlindungan serta perawatan khusus, termasuk perlindungan hukum sebelum maupun sesudah mereka dilahirkan.

Perlindungan terhadap anak ini telah menjadi kesepakatan internasional sebagaimana diamanatkan dalam deklarasi Jenewa tentang Hak Anak-anak tahun 1924, yang selanjutnya telah mendapat pengakuan dalam Deklarasi Sedunia tentang Hak Asasi Manusia serta ketentuan hukum yang dibuat oleh badanbadan khusus dan organisasi-organisasi Internasional yang memberi perhatian bagi kesejahteraan anak-anak. Jauh hari Majelis Umum PBB memaklumkan

3 Paulus Hadisuprapto, Makalah Dengan Judul " Prospek Hukum Pidana Anak di Indonesia", Semarang, 15-17 April 2006 
Deklarasi Hak Anak-Anak dengan maksud agar anak-anak dapat menjalani masa kecil yang membahagiakan, berhak menikmati hak-hak dan kebebasan baik kepentingan mereka sendiri maupun untuk kepentingan masyarakat.

Majelis Umum PPB menghimbau agar pemerintah negra-negara untuk mengakui mengakui dan memperjuangkan pelaksanaan hak-hak anak melaui undang-undang maupun peraturan lainnya yang sesuai dengan asas-asas perlindungan terhadap hak-hak anak. ${ }^{4} \mathrm{UU}$ No. 3 Tahun 1997 tentang Pengadilan Anak dibuat pada dasarnya bertujuan untuk menciptakan perlindungan khusus kepentingan hukum anak yang terlibat tindak pidana, yang sebelumnya dalam perundang-undangan yang ada dirasa tidak banyak memberikan perlindungan terhadap anak baik secara fisik maupun mental. 5

Setelah diundangkannya UU No. 3 Tahun 1997 diharapkan aparat penegak hukum mulai dari penyelidikan hingga pemeriksaan diperadilan, dapat memperlakukan anak secara khusus dengan dibekali pengetahuan khusus untuk menangani tindak pidana yang dilakukan anak. Jika ditelaah secara konprehensif ketentuan hukum substantive dan hukum ajektif yang diformulasikan dalam UU No. 3 Tahun 1997, dapatlah dikatakan belum ada pengaturan secara utuh pengaturan hukum pidana anak.

Sistem hukum dari undang-undang ini masih belum terlepas secara menyeluruh dari KUHP dan KUHAP sebagai lex specialis, karena asas-asas dan ajaranajaran dari ketentuan hukum pidana yang terkandung dalam KUHP dan KUHAP tetap diberlakukan dalam

4 Wagiarti Soetodjo, Hukum Pidana Anak, (Bandung : Refika Aditama, 2006), halaman 77

${ }^{5}$ Konsiderans huruf a UU No.3 tahun 1997 tentang Pengadilan Anak ketentuan UU No. 3 Tahun 1997. Ketentuan hukum substantive UU No. 3 Tahun 1997 masih terikat pada KUHP walaupun telah ada ketentuan tersendiri mengenai straf soot dan straf maat serta straf modus sistem pemidanaan yang berbeda dari KUHP, karena Pasal 45, Pasal 46,dan Pasal 47 KUHP secara expresis verbis dinyatakan tidak berlaku lagi oleh ketentuan Pasal 67 UU No.3 Tahun 1997.

Karena UU No. 3 Tahun 1997 hanya menyatakan, bahwa Pasal 45 s/d 47 KUHP saja yang "dinyatakan tidak berlaku". Ini berarti, secara juridis pasalpasal lain di dalam KUHP tetap berlaku, antara lain ketentuan tentang "pidana" (Psl. 10 s/d 43), termasuk di dalamnya tentang "strafmodus" (seperti "pidana bersyarat" dan pelepasan bersyarat"), ketentuan tentang "percobaan" (Psl. 53 dan 54), tentang "penyertaan" (Psl. 55-56 dst.), tentang "concursus", "alasan penghapus pidana", "alasan hapusnya kewenangan menuntut dan menjalankan pidana" dan sebagainya.

Bahkan aturan khusus di dalam Buku II dan III KUHP juga masih berlaku untuk anak, termasuk di dalamnya ketentuan tentang "pengulangan" (recidive). Sebagian besar ketentuan KUHP tetap berlaku, karena ketentuan-ketentuan itu memang tidak diatur di dalam UU No. 3 Tahun 1997 dan juga tidak ada ketentuan di dalam "Ketentuan Peralihan" (Bab VII) maupun dalam "Ketentuan Penutup" (Bab VIII) UU No. 3Tahun 1997 yang menyatakan secara umum, bahwa "semua ketentuan yang bertentangan dengan UU ini dinyatakan tidak berlaku". Ketentuan umum pidana bersyarat dalam Pasal $14-$ f KUHP, malahan oleh Pasal 29 UU No. 3 Tahun 1997 dengan restriktif limitative "memperkaku" hanya untuk pidana penjara dan lamanya masa percobaan maksimum 3 tahun (dengan tidak membedakan antara kejahatan dan pelanggaran). 
Menurut Barda Nawawi Arief, ketentuan KUHP tentang pidana bersyarat dapat dijatuhkan tidak hanya untuk pidana penjara, tetapi juga untuk pidana kurungan, denda yang sangat berat, dan bahkan juga untuk pidana tambahan (apabila hakim tidak menentukan lain). Masa percobaannya, menurut KUHP, dibedakan antara kejahatan dan pelanggaran. ${ }^{6}$ Padahal dilihat dari ide/filosofi pidana bersyarat sebagai salah satu bentuk alternatif dari pidana perampasan kemerdekaan atau sebagai salah satu bentuk "non-custodial measures", dan juga sebagai salah satu bentuk "strafmodus", maka seharusnya juga dapat diberikan untuk pidana kurungan dan jenis-jenis pidana lainnya.

Dengan kata lain, peluang untuk memberikan pidana bersyarat kepada anak itu seharusnya lebih diperbesar sesuai dengan ide dibuatnya ketentuan pidana khusus untuk anak serta amanat pada konsiderans UU No. 3 Tahun 1997 itu sendiri. Dirasakan janggal, kalau terhadap orang dewasa saja peluang yang lebih besar itu tersedia (seperti yang diatur dalam KUHP), sedangkan peluang untuk anak dipersempit. Di sisi lain beberapa formulasi ketentuan hukum ajektif dari UU No. 3 Tahun 1997 telah menentukan sendiri mengenai batasbatas yang menjadi kompetensi khusus dalam mengadili anak, yaitu: ${ }^{7}$

1. pembatasan umur orang yang dapat diperiksa tahap penyidikan hingga disidangkan dalam acara persidangan

6 Barda Nawawi Arief, Perkembangan Sistem Pemidanaan di Indonesia, Penataran Nasional HUKUM PIDANA DAN KRIMINOLOGI XI Tahun 2005, Kerja sama FH UBAYA, Forum Pemantau Pemberantasan Korupsi, dan ASPEHUPIKI, di Hyatt Hotel, Surabaya, tgl. 14-16 Maret 2005.

${ }^{7}$ Penjelasan Umum UU No.3 tahun 1997 pada alenia ke -6 anak, yaitu berumur kurang dari 8 tahun hingga 18 tahun sebagaimana diatur Pasal 1 butir 1 dan Pasal 4 ayat (1) UU No. 3 Tahun 1997;

2. Kekhususan dari ruang lingkup pembatasan yang masuk kompetensi dalam perkara anak nakal ditentukan Pasal 1 ayat 2 .

3. Kehususan aparat penegak hukum yang menangani perkara anak nakal, mulai ditingkat penyidikan, penuntutan, dan persidangan, sebagaimana ditentukan Pasal 1 ayat 5, 6, dan 7 .

4. Adanya pembimbingan kemasyarakatan yang terdiri dari Pembimbing Kemasyarakatan, Pekerja Sosial dan Pekerja Sosial Sukarela yang mempunyai peran penting untuk pertimbangan putusan hakim dalam peradilan anak. Ketentuan tentang hal itu ditemukan sebagaimana diatur dalam Pasal 1 ayat 11 .

5. Suasana pemeriksaan dalam persidangan dibedakan dengan pemeriksaan orang dewasa, yaitu dikondisikan suasana kekeluargaan dan bersahaja, diatur dalam ketentuan Pasal 42 ayat 1.

6. Jika dalam tindak pidana deelneming yang melibatkan anak, pemeriksaan terhadap anak dilakukan secara splitsing dari pelaku orang dewasa. Diatur dalam ketentuan Pasal 7.

7. Pemeriksaan sidang dilakukan secara tertutup, ditentukan Pasal 8 ayat 1 .

8. Pemeriksaan perkara dilakukan oleh hakim tunggal, ditentukan Pasal 11, 14 dan 18.

9. Masa penahanan lebih singkat dari orang dewasa, diatur Pasal 44 s/d 49.

10. Tidak mengenal hukuman pidana mati, dan untuk hukuman badan hanya mengenal pidana penjara sementara waktu maksimal 10 tahun, diatur dalam Pasal 22 s/d 32.

Kewenangan sidang anak dalam undang-undang ini hanya mengatur tentang memeriksa dan menyelesaikan 
perkara anak nakal, yaitu anak yang melakukan tindak pidana atau yang melakukan perbuatan yang dinyatakan terlarang bagi anak (Pasal 21). Bagi anak nakal dapat dijatuhkan sanksi pidana dan/atau tindakan. Sanksi pidana terdiri dari pidana pokok dan pidana tambahan. Pidana pokok terdiri atas pidana penjara, pidana kurungan, pidana denda dan pidana pengawasan. Pidana tambahan terdiri atas pidana perampasan barangbarang tertentu dan/atau pembayaran ganti kerugian, sebagaimana diatur Pasal 23, 28, 29, 30, dan 32. Tindakan terdiri atas pengembalian anak pada orang tua, penyerahan anak pada Negara atau penyerahan anak kepada Departemen Sosial dan Organisasi Kemasyarakatan, selain itu ditambahkan pula teguran dan syarat tambahan lain (Pasal 24). ${ }^{8}$ Petugas Kemasyarakatan dalam ketentuan Pasal 33 ditentukan terdiri dari:

1. Pembimbing Kemasyarakatan;

2. Pekerja Sosial dari Departemen Sosial;

3. Pekerja Sosial dan Organisasi Sosial Kemasyarakatan.

Pembimbing Kemasyarakatan adalah petugas pemasyarakatan pada Balai Pemasyarakatan (BAPAS) bertugas melakukan bimbingan warga binaan pemasyarakatan (Pasal 1 angka 11). Petugas Kemasyarakatan bertugas:

1. Membantu memperlancar tugas penyidik, penuntut umum dan hakim dalam perkara anak nakal, baik di dalam maupun di luar sidang anak, dengan membuat laporan hasil penelitian kemasyarakatan;

2. Membimbing, membantu dan mengawasi anak nakal yang berdasarkan putusan pengadilan dijatuhi pidana bersyarat, pidana pengawasan, pidana denda, diserahkan kepada Negara dan harus mengikuti latihan

8 Penjelasan Umum UU No.3 tahun 1997 alenia ke-8 kerja atau anak yang memperoleh pembebasan bersyarat dari Lembaga Pemasyarakatan (Pasal 34 ayat 1). Petugas Sosial bertugas membimbing, membantu dan mengawasi anak nakal yang berdasarkan putusan pengadilan diserahkan kepada Departemen Sosial untuk mengikuti pendidikan, pembinaan dan latihan kerja.

Di dalam pelaksanaannya Petugas Kemasyarakatan berkoordinasi dengan Pembimbing Kemasyarakatan (Pasal 34 ayat 3). Pekerja Sosial Sukarela (seperti LSM) yang memiliki pengetahuan, dan kemampuan serta berminat membantu anak nakal ditugaskan membantu dan berkoordinasi dengan Pembimbing Kemasyarakatan dan Petugas Sosial dari Departemen Sosial (Pasal 39 ayat 1).

Dengan ketentuan tersebut, maka peran Pembimbing Kemasyarakatan dari BAPAS dalam perkara sidang anak mengalami perobahan peran yang cukup signifikan, sebab dengan ketentuan UU No. 3 Tahun 1997 ini kedudukan BAPAS tidak lagi sepenuhnya berada di lini belakang dalam mata rantai proses pemidanaan anak.

BAPAS sudah sejak semula dari awal tindakan pro justitia, yaitu mulai dari tahap penyidikan, penuntutan, dan persidangan sudah dituntut perannya untuk memberikan laporan kemasyarakatan anak pelaku delinkuen. Perkembangan peran BAPAS ini sudah barang tentu akan menuntut pembenahan personalia (staffing) dan kualitas SDM petugas BAPAS yang lebih professional terhadap penanganan perkara anak agar tercapai yang dikehendaki dari tujuan dibuatnya undang-undang ini dalam melindungi anak. Dari ketentuan substantive UU No. 3 Tahun 1997 yang mengatur tentang peradilan anak nakal tidak ada mengatur tentang diversi, yaitu membuat pengaturan dari bentuk penyimpangan penanganan anak pelaku 
delinkuen di luar jalur yustisial konvensional sebagaimana dikehendaki dalam Commentary Rule 11 Resolusi PBB 40/33, UN Standard Minimum Rule for the Administration of Juvenile Justice. Diversi sangat penting untuk diperhatikan dalam penanganan anak pelaku delinkuen, diversi dapat menghindarkan anak dari proses stigmatisasi yang lazimnya terjadi dalam proses pemidanaan anak lewat sistem peradilan pidana anak.

Bila diperhatikan ketentuan-ketentuan yang terkandung dalam Resolusi PBB 40/33, dan kecenderungan pengaturan proses pemidanaan anak dibeberapa Negara (Amerika Serikat, Inggris, Negara Belanda, Australia, Selandia Baru dan Jepang) semuanya mengatur diversi dalam penanganan anak pelaku delinkuen. Dari sisi perlindungan kepentingan terbaik anak, maka keberadaan diversi ini sangat diperlukan, sebab melalui diversi tersebut penuntutan pidana gugur dan criminal track-record anakpun serta stigmatisasi anak tidak terjadi.

Penangkapan, penahanan, dan pemenjaraan anak seharusnya menjadi pilihan terakhir dari aparat penegak hukum terkait, sebagaimana diamanatkan UU Pengadilan Anak, maupun UU Perlindungan Anak. Akan tetapi, realita menunjukkan antara law in book (teori) dengan law in action (praktik) kerap terjadi kesenjangan di negeri ini. Bahkan, penerapan hukum sering dirasakanoleh si lemah begitu keras, kaku, dan salah kaprah. Diterapkannya proses peradilan formal secara mutlak setiap kasus anak nakal dengan dijatuhi pidana penjara pembinaannya harus dilakukan di lembaga pemasyarakatan khusus anak, jaminan terhindarnya dari stigmatisasi dan mempengaruhi criminal track-record anak dengan kondisi pelayanan Lembaga Pemasyarakatan Anak saat ini masih menjadi pertanyaan besar.

Sebagai sutau gambaran dari penelitian Paulus Hadisuprapto pada LP
Khusus anak ternyata ditemukan tidak semua anak yang dijatuhi pidana penjara ditempatkan dan bina di LP Anak, berarti anak-anak lainnya berada dalam LP bukan khusus untuk anak termasuk pembinaannya. Sebagian besar menyatakan bahwa pengalaman mereka mengindikasikan bahwa perlakuan para aparat penegak hukum terhadap mereka selama dalam proses pemidanaan (sejak dari kepolisian, kejaksaan hingga pengadilan) cenderung kurang dihargai pribadinya sebagai anak.

Peradilan pidana anak menunjukkan bahwa persyaratan profesionalitas aparat penegak hukum di bidang anak tidak terpenuhi, persyaratan sebagai penyidik anak, penuntut umum anak dan hakim anak hanya berdasarkan formalitas saja. Artinya bahwa penunjukan penyidik anak, penuntut umum anak dan hakim anak hanya berdasarkan atas Surat Penunjukkan dari atasan mereka masingmasing dan tidak dilihat akan komitmen dan pemahamannya terhadap permasalahan anak-anak seperti disyaratkan oleh UU Pengadilan Anak. Implementasi UU No. 3 Tahun 1997 tentang Pengadilan Anak dalam prakteknya cenderung memberikan stigma atas diri anak. Proses stigmatisasi ini berlangsung di tingkat penyidikan, penuntutan, persidangan di pengadilan hingga di tempat pembinaan. Keadaan ini sudah barang tentu akan sangat merugikan perkembangan jiwa anak pelaku di masa datang. Dari kajian kriminologi mengisyaratkan bahwa stigmatisasi atas diri anak pelaku delinkuen di samping akan membekas bagi jiwa anak, juga sangat potensial sebagai factor kriminogen- melalui proses yang disebut "self-fulfiling prophecy" anak cenderung mengindentifikasikan dirinya sesuai dengan "cap" yang disandangnya dan akan mengulangi lagi perbuatan kenakalannya di masa mendatang (secondary deviance). 
Pada intinya ketentuan ius constitutum mengenai Pengadilan Anak saat ini tidak efektif sebaimana yang digariskan pada konsiderans dan penjelasan Undang-undang itu sendiri, disebabkan pada undang-undang itu tidak memberikan ruang dan jalan keluar untuk melakukan diskresi dan diversi kepada hakim setelah melihat penilaian BAPAS. Padahal diskresi dan diversi merupakan klep pengaman bagi anak-anak pelaku delinkuen tertentu, untuk terhindar dari proses konvensional sistem peradilan pidana anak yang lazimnya memiliki dampak negative terhadap terjadinya stigmatisasi anak. Sebaliknya pada tataran ius operatum ketentuan UU No. 3 Tahun 1997, penegakan hukumnya belum mampu dilakukan oleh aparat penegak hukum yang profesional membidangi anak sebagaimana dikehendaki undang-undang itu sendiri. Dalam kajian kriminologi, stigmatisasi yang dialami anak menjadi factor pemicu kriminogen dalam mengulangi kenakalan berikutnya.

\section{Beberapa Corak Peradilan Anak}

Gordon Bazomore dalam tulisannya "Three Paradigms of Juvenile Justice" memperkenalkan tiga corak atau model peradilan anak, yaitu:

1. model pembinaan pelaku perorangan (individual treatment model);

2. model retributive (retributive model);

3. model restorative (restorative model)

Model pembinaan pelaku perorangan

(individual treatment model) dan model retributive (retributive model) telah mempercayakan campur tangan peradilan anak dan menetapkan dengan pasti parameter-parameter kebijakan tentang peradilan anak. Di dalam model pembinaan pelaku perorangan, persidangan anak dilihat sebagai suatu agensi quasi kesejahteraan dengan mandat peradilan yang samara-samar, pembinaan dilandaskan pada cara medik terapeutik, tentang sebab-sebab timbulnya delinkuensi anak. Atas dasar itu delinkuensi anak dipandang sebagai simptomatik dan gangguan, dan hakikat serta tingkat keseriusannya dilihat tidak lebih sebagai persoalan yang membutuhkan pelayanan terapeutik untuk mengkoreksi gangguangangguan yang ada sebelumnya.

Model pembinaan pelaku perorangan di negara-negara Eropa dikenal sebagai "model kesejahteraan anak", berangkat dari satu cara pandang bahwa kejahatan atau delinkuensi anak tidak dipertimbangkan atau diharapkan pada perangkat nilai-nilai, melainkan lebih dilihat sebagai tanda tidak fungsionalnya sosialisasi. Intervensi adalah sarana untuk mencoba meralat perilaku penyimpangan social lewat pemberian sanksi terhadap masalah personal seseorang dan kebutuhan pembinaan anak pelaku delinkuen. Corak atau model pembinaan pelaku perorangan ini dirasakan kelemahannya terutama tidak terjaminnya timbul stigmatisasi, paternalistic, mahal, tidak memadai, dan jaminan hukumnya lemah serta diragukan intensitasnya.

Di samping itu, model ini dilihat masih belum berhasil mengarahkan secara formal kebutuhan untuk meningkatkan efektivitas sanksi terhadap anak pelaku delinkuen dan gagal memainkan peran dari peradilan anak dalam kerangka penyelamatan publik. Keputusan bersifat ambivalen dan tak taat asas (inconsistent) serta cenderung menyembunyikan maksud pemidanaan dengan mengatasnamakan keselamatan publik. Seiring dengan kritik terhadap model pembinaan pelaku perorangan terhadap anak tersebut, kemudian muncul tuntutan untuk segera mereformasi peradilan anak. Arah reformasi tertuju pada pengaplikasian filosofis "pemberian ganjaran". Pengaplikasian filosofis itu dimaksudkan sebagai upaya untuk merasionalisasikan ketidakpastian pembuatan keputusan dalam persidangan anak, dan untuk menegas- 
kan kembali pentingnya fungsi sanksi. Konsekuensi yang muncul kemudian adalah tuntutan akan perlunya mengadopsi pedoman pemberian pidana yang pasti, undang-undang tentang anak tidak lagi menekankan rehabilitasi dan membuang kerangka acuan berorientasi pada keperluan pelaku.

\section{Model Restorative Justice Suatu Alternatif Konsep Peradilan Anak Indonesia}

Model peradilan anak restorative berangkat dari asumsi bahwa tanggapan atau reaksi terhadap perilaku delinkuensi anak, tidak akan efektif tanpa adanya kerja sama dan keterlibatan dari korban, pelaku dan masyarakat. Prinsip yang menjadi dasar pada model peradilan restorative ini bahwa keadilan paling baik terlayani, apabila setiap pihak menerima perhatian secara adil dan seimbang, aktif dilibatkan dalam proses peradilan dan memperoleh keuntungan secara memadai dari interaksi mereka dengan sistem peradilan anak.

Ciri pembeda model restorative dengan kedua model lainnya terletak pada sisi pandang terhadap perilaku delinkuensi anak. Menurut model restorative, perilaku delinkuensi anak adalah perilaku yang merugikan korban dan masyarakat. Tanggapan peradilan restorative terhadap delinkuensi terarah pada perbaikan kerugian itu dan penyembuhan luka masyarakat. Peradilan restorative tidak bersifat punitive, tujuan utamanya adalah perbaikan luka yang diderita oleh korban, pengakuan pelaku terhadap luka yang diakibatkan oleh perbuatannya dan konsiliasi serta rekonsiliasi dikalangan korban, pelaku dan masyarakat. Model peradilan restoratif juga berkehendak untuk merestorasi kesejahteraan masyarakat melalui cara-cara menghadapkan pelaku anak pada pertanggungjawaban atas perilakunya, korban yang biasanya dihalangi ikut berperan serta dalam proses peradilan kini diberi kesempatan untuk berperan serta di dalam proses.

Proses restorative justice pada dasarnya dilakukan melalui diskresi (kebijaksanaan) dan diversi ini, merupakan upaya pengalihan dari proses peradilan pidana ke luar proses formal untuk diselesaikan secara musyawarah. Penyelesaian melalui musyawarah sebetulnya bukan hal baru bagi bangsa Indonesia. Sebelum pendudukan Belanda, bangsa kita sudah memiliki hukum sendiri, yaitu hukum adat. Hukum adat tidak membedakan penyelesaian perkara pidana dengan perkara perdata, semua perkara dapat diselesaikan secara musyawarah dengan tujuan untuk mendapatkan keseimbangan atau pemulihan keadaan.

Sasaran akhir konsep peradilan restorative ini mengharapkan berkurangnya jumlah anak-anak yang ditangkap, ditahan, dan divonis penjara; menghapuskan stigma/cap dan mengembalikan anak menjadi manusia normal sehingga diharapkan dapat berguna kelak di kemudian hari; pelaku pidana anak dapat menyadari kesalahannya, sehingga tidak mengulangi perbuatannya mengurangi beban kerja polisi, jaksa, rutan, pengadilan, dan Lapas; menghemat keuangan negara tidak menimbulkan rasa dendam karena pelaku telah dimaafkan oleh korban korban cepat mendapatkan ganti kerugian; memberdayakan orang tua dan masyarakat dalam mengatasi kenakalan anak dan; pengintegrasian kembali anak ke dalam masyarakat.

Adapun sebagai mediator dalam musyawarah dapat diambil dari tokoh masyarakat yang terpercaya dan bila kejadiannya di sekolah dapat dilakukan kepala sekolah atau guru. Syarat utama dari penyelesaian melalui musyawarah pemulihan adalah adanya pengakuan dari pelaku serta adanya persetujuan dari pelaku beserta keluarganya dan korban untuk menyelesaikan perkara melalui musyawarah pemulihan. Jadi, musya- 
warah tidak boleh didasarkan atas paksaan. Apabila pihak-pihak tidak menghendaki penyelesaian melalui musyawarah pemulihan, maka proses peradilan baru berjalan. Dalam konsep restorative ini proses peradilan sebagai ultimum remedium, apabila pintu diskresi tidak ditemukan.

Proses peradilan yang diharapkan adalah proses yang dapat memulihkan, artinya perkara betul-betul ditangani aparat penegak hukum yang mempunyai minat, perhatian, dedikasi, dan memahami masalah anak, dan telah mengikuti pelatihan restorative justice, serta penahanan dilakukan sebagai pilihan terakhir dengan mengindahkan prinsipprinsip dasar dari Konvensi Hak-hak Anak yang telah diadopsi ke dalam UU Perlindungan Anak. Apabila anak terpaksa harus ditahan, penahanan tersebut harus di rutan khusus anak, dan apabila terpaksa harus dihukum penjara, anak harus ditempatkan di lapas anak. Baik di rutan maupun di lapas, anak tetap harus bersekolah dan mendapatkan hak asasinya sesuai dengan The Beijing Rules (Peraturan Minimum Standar PBB Mengenai Administrasi Peradilan bagi Anak) agar mereka dapat menyongsong masa depan yang cerah, karena pengabaian terhadap hak-hak anak adalah juga pengabaian terhadap masa depan bangsa dan Negara.

\section{PENUTUP}

Peradilalan anak dalam ketentuan UU No. 3 Tahun 1997 dilahirkan adalah merupakan suatu format hukum untuk memberikan perlindungan terhadap anak melalui proses hukum formal, dengan harapan anak sebagai asset bangsa walaupun harus mempertanggungjawabkan perbuatannya sebagai anak nakal diharapkan tidak menimbulkan pengaruh negative pada jiwa anak.
Namun secara normative kekurangandari UU ini pengaturan untuk perlindungan terhadap anak dirasakan lebih dipersempit jika dibandingkan pada ketentuan sebelum hukum yang berlaku sebelumnya. Implementasi ketentuan UU No. 3 Tahun 1997 ini setelah berusia 10 tahun banyak menimbulkan permasalahan sebagai sarana hukum perlindungan tehadap anak, disebabkan tidak diadakannya pintu klep pengaman dalam proses penegakan hukum terhadap anak nakal.

Diversi sebagai bentuk diskresi yang dikenal dalam proses hukum, merupakan salah satu prinsip pengecualian yang perlu dipikirkan sebagai konsep proses peradilan anak pada tataran ius constituendum. Model restorative justice adalah salah satu model peradilan anak, dalam rangka melindungi anak agar terhindar dari trauma psikis dan lebel/cap bekas penjahat. Dalam ketentuan UU No. 3 Tahun 1997 tidak memberikan ruang bagi aparat hukum untuk melakukan diskresi legal, dalam menerapkan proses peradilan anak.

\section{DAFTAR PUSTAKA}

Barda Nawawi Arief, Bunga Rampai Kebijakan Hukum Pidana, (Bandung : Citra Aditya Bakti, 1996)

,Perkembangan Sistem Pemidanaan di Indonesia, Penataran Nasional HUKUM PIDANA DAN KRIMINOLOGI XI Tahun 2005, Kerja sama FH UBAYA, Forum Pemantau Pemberantasan Korupsi, dan ASPEHUPIKI, di Hyatt Hotel, Surabaya, tgl. 14-16 Maret 2005. 
Paulus Hadi Soeprapto, Pemberian Malu Reintegratif Sebagai Sarana Non Penal Penanggulangan Perilaku Delinkuensi Anak, (Undip Press, 2003)

Judul "Prospek Hukum Pidana Anak di Indonesia", Semarang, 1517 April 2006

Sudarto, Hukum dan Hukum Pidana, (Bandung : Alumni, 1977)

Wagiarti Soetodjo, Hukum Pidana Anak, (Bandung : Refika Aditama, 2006)
Kitab Undang-Undang Hukum Pidana UU No. 8 Tahun 1981 tentang Kitab Undang-Undang Hukum Acara Pidana.

UU No. 3 Tahun 1997 tentang Pengadilan Anak

UU No. 4 Tahun 1979 tentang Kesejahteraan Anak

UU No. 23 Tahun 2002 tentang Perlindungan Anak

Keppres No. 36 Tahun 1990 tentang Pengesahan Konvensi Hak-Hak Anak 